\title{
Different MPPT Controlling Techniques for Standalone Solar System for Improvement in Power Generation
}

\author{
Megha Dokale, Deepak Sonje, M.Venkateswara Reddy
}

\begin{abstract}
A simple and economic performance analysis of varied MPPT dominant techniques for standalone renewable energy sources presented during this paper. These years so as to satisfy the event in power demands and to shrink the overall warming, sustainable power sources based generally framework is functioning. Out of the sustainable power sources, sunlight based power is the prime cause. For the efficient use of yield vitality of $P V$ array, it's fundamental to work $P V$ frameworks inside maximum point tracking(MPPT). This work introduces an overall investigation of control calculations. The DC bus energy is reliably maintained to accomplish the consistent electrical yield. The Model of the structure is formulated in Matlab/Simulink to look at the work analysis of the techniques.

Keywords: MPPT technique, PV Array, P\&O, I\&C, O.C.V PID, Buck, PWM Technique, VSI, MATLAB/Simulink.
\end{abstract}

\section{INTRODUCTION}

The growing vitality during the planet and contamination of natural habitats, are trying to find consideration from designing and science club since few periods. The effectiveness of PV array, at current has touched to $15-16 \%$. Nowadays, PV energy renovation is observed commonly of the hopeful replacements electricity generating systems. The activity of PV modules depends on ecological elements, i.e., radiation and climatic temperature, that influences every current-voltage (I-V) and powervoltage $(\mathrm{P}-\mathrm{V})$ qualities of the Photovoltaic. Consequently, MPPT control is predicted to decrease the effect of the ecological components and to utilize the facility from PV array ideally. MPPT systems are catching rich consideration due to their significant improvements inside the PV vitality. Differing kinds of MPPT calculations, e.g., Perturb and Observation (P\&O), Fractional Over Voltage (FOV) technique and Incremental Conductance (IC) are clarified.

\section{DESIGN OF PLANNED STRUCTURE}

The design of PV framework related with burden which is appeared in Figure 1. The PV framework creates sunlight based cells as their organizational unit which can produce power utilizing the sun oriented irradiance.

\section{A. PV Array:}

The PV system has power conditioning unit to regulate the generated power. Connected in the middle of the PV source and burden. To get Extreme

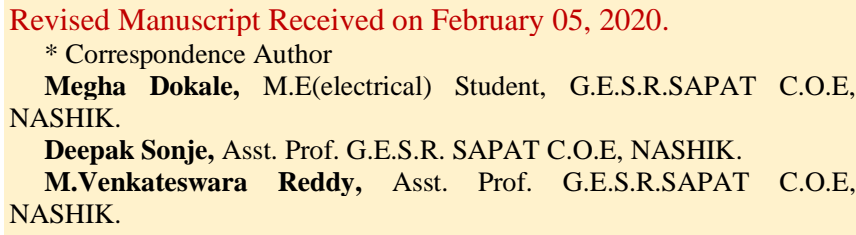

(C) The Authors. Published by Blue Eyes Intelligence Engineering and Sciences Publication (BEIESP). This is an open access article under the CC BY-NC-ND license (http://creativecommons.org/licenses/by-nc-nd/4.0/)
Power MPPT methods were modified in the system.

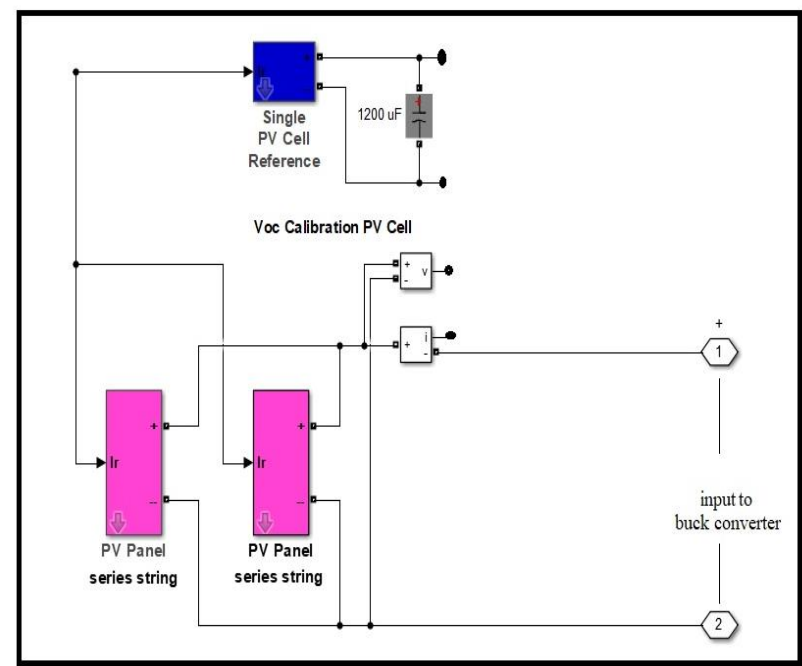

Solar Cell output current is given by:

Is = Ip - Io * $(\exp ((\mathrm{V}+\mathrm{I} * \mathrm{Rs}) /(\mathrm{N} * \mathrm{Vt}))-1)-\left(\mathrm{V}+\mathrm{I}^{*} \mathrm{Rs}\right) / \mathrm{Rp}$ Where
Ip -light generated current,
Io -diode saturation current,
$\mathrm{Vt}$ - thermal voltage,
$\mathrm{N}$-emission coefficient

\section{B. DC-DC Buck}

A buck converter (step-down) might be a DC-to-DC power that steps down voltage from its input to its output. The fundamental dc-dc buck converter topology is shown in Fig. It includes controlled switch, Partner uncontrolled switch diode (D), Partner in electrical device L, Partner in capacitance $\mathrm{C}$ and a load resistance $\mathrm{R}$. within the description of action it's assumed that each one the elements square measure ideal and conjointly the works in Continuous conductivity mode (CCM).

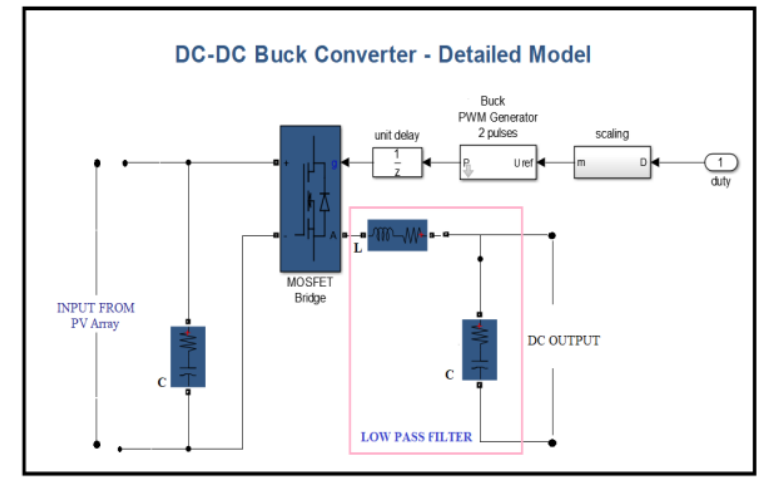




\section{DC-AC (VSI)}

The important aim of static power is to deliver associate ac output wave shape from a dc power supply.

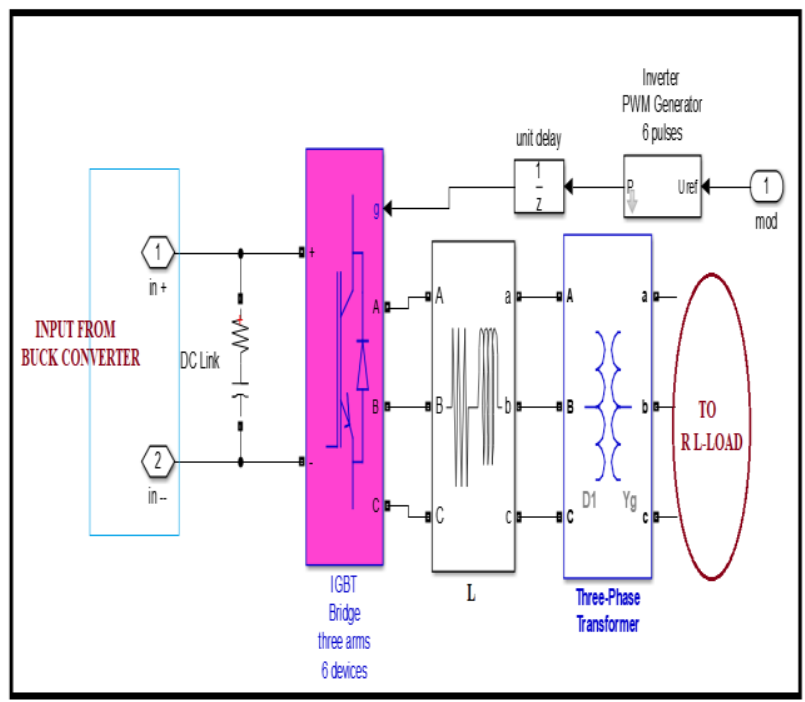

Allowing ac output wave shape, these topologies will be thought of as voltage source inverters (VSIs), wherever the severally controlled ac output could be a voltage wave shape.

\section{COMPARISON OF DIFFERENT MPPT TECHNIQUE}

\section{A. P\&O MPPT Technique}

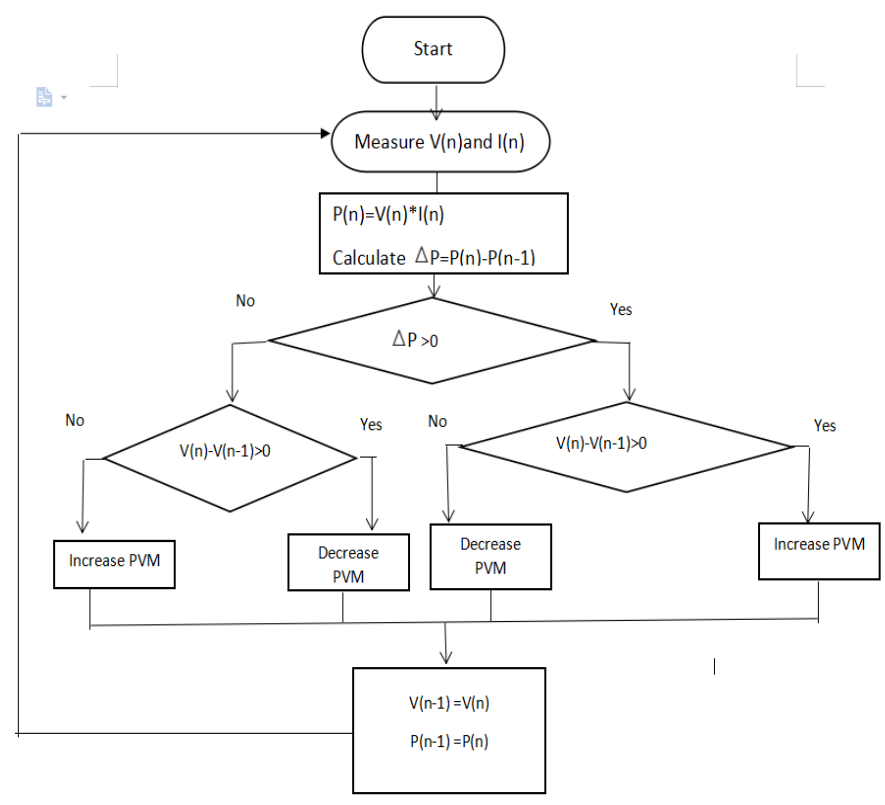

Fig3.1. P\&O Methodology

In this methodology uses only variables voltage. To sense the voltage of PV array then the value of implementation is a smaller amount and thus direct to instrument. To escape this disadvantage, we can use IC methodology.

\section{B. I\&C MPPT Technique}

This methodology uses two variables voltage and current. Sensor signified the output voltage and current of the PV array. At MPPT the slant of the PV curve is zero.

$(\mathrm{dP} / \mathrm{dV}) \mathrm{MPPT}=\mathrm{d}(\mathrm{VI}) / \mathrm{dV}$
$0=\mathrm{I}+\mathrm{VdI} / \mathrm{dVMPPT}$

$\mathrm{dI} / \mathrm{dVMPPT}=-\mathrm{I} / \mathrm{V}$

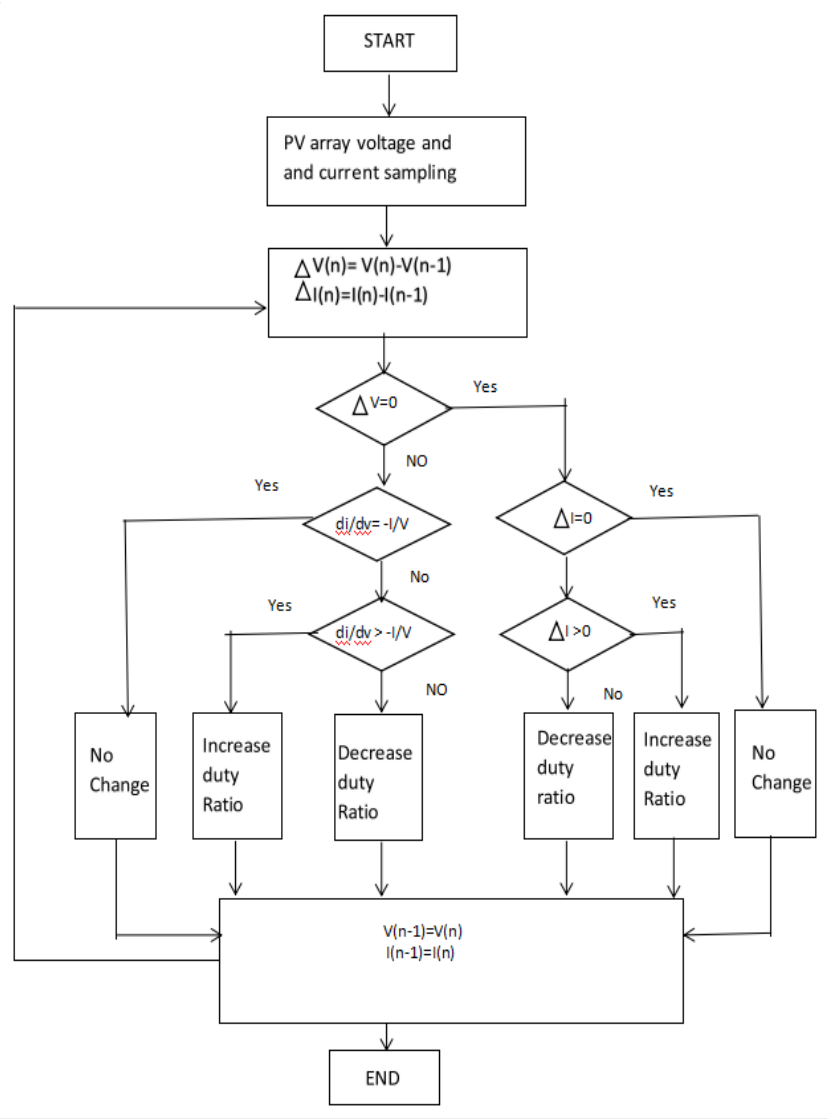

Fig 3.2. IC Algorithm

C. Fractional Over Voltage MPPT Technique

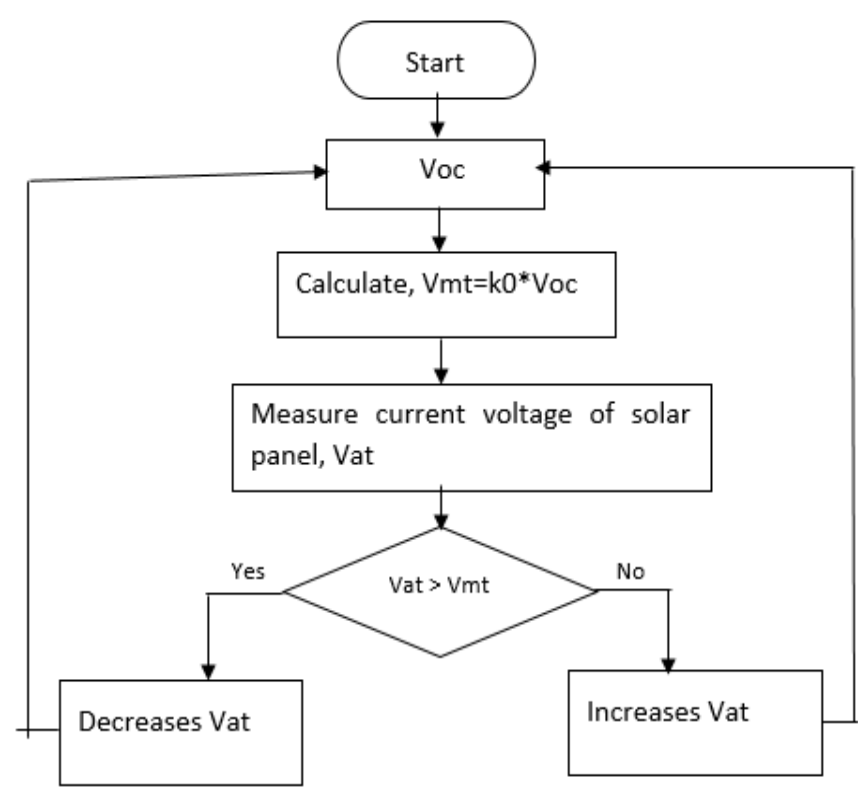

Fig3.1. Fractional Over Voltage Algorithm

The near direct connection among Vmt and Voc of the PV exhibit, underneath factor irradiance and temperature levels, has offered ascend to the inadequate Voc procedure. Vmt = $\mathrm{k} 0$ Voc where $\mathrm{k} 0$ is a steady of proportionality. Since $\mathrm{k} 1$ is subject to the attributes of the PV array being utilized, this 
strategy causes a few burdens, including brief loss of power.

\section{DESIGN OF PROPOSED SYSTEM IN MATLAB/SIMULINK}

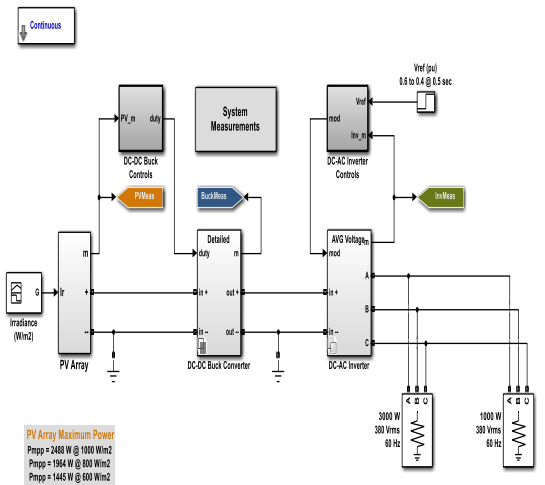

Fig 4.1 Main Simulink Model (constant load)

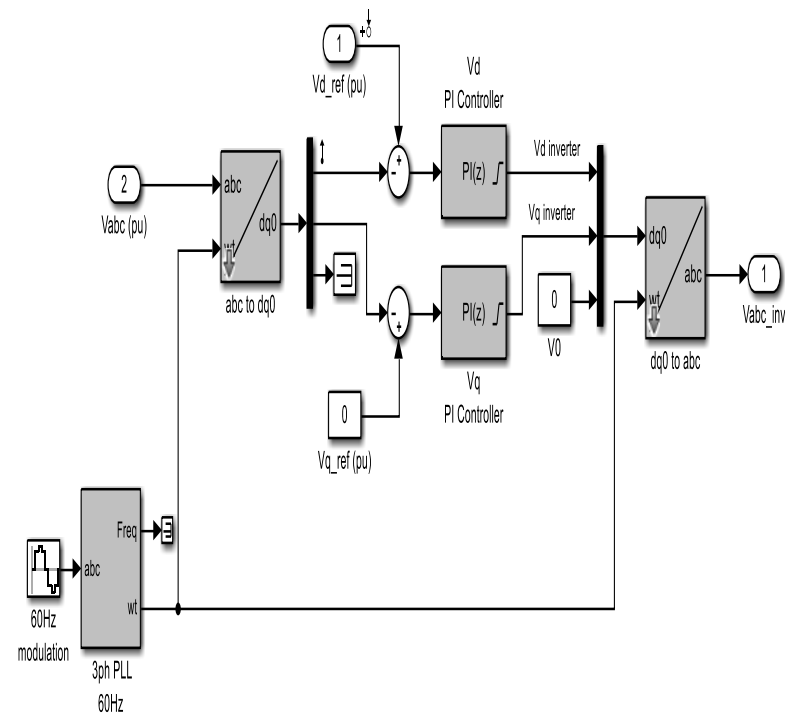

Fig 4.2 Controller for Inverter

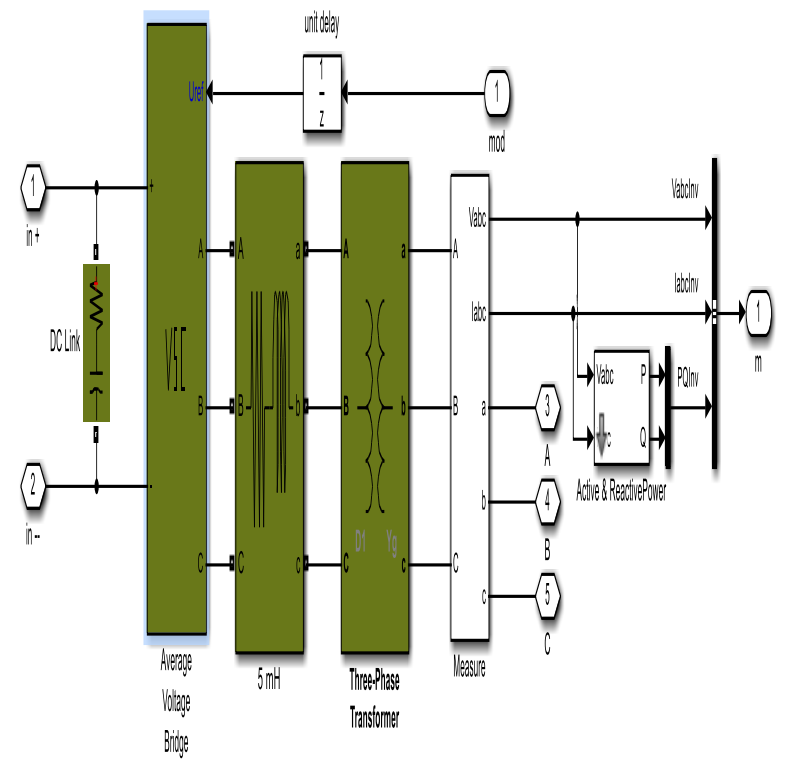

Fig.4.3. DC-AC Inverter

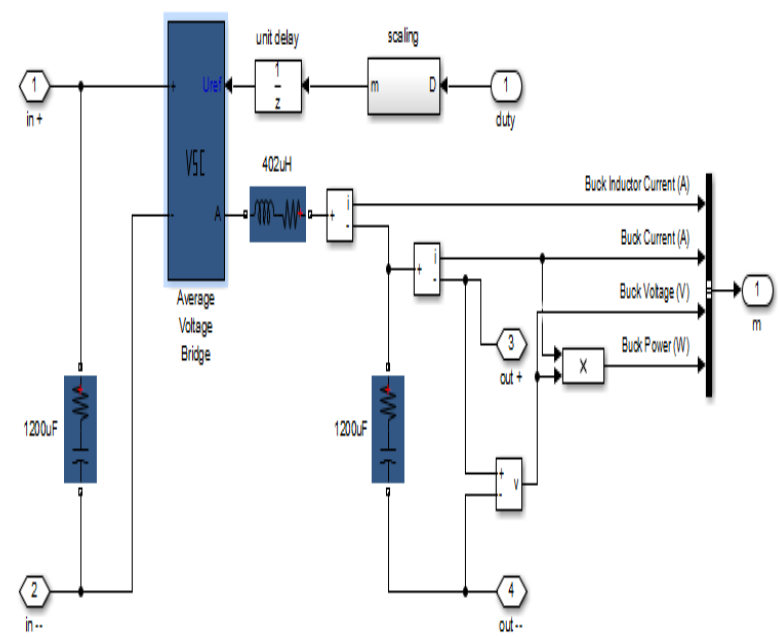

Fig.4.4. Dc-Dc Buck

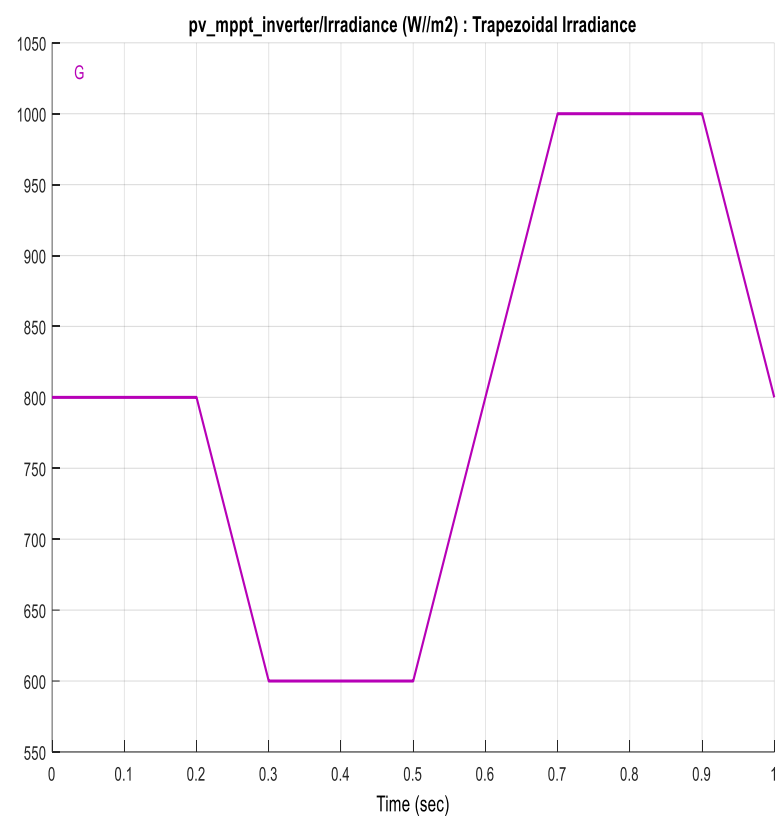

Fig. 4.5. Solar radiation Trapezoidal irradiance type

\section{A. Simulation Results}

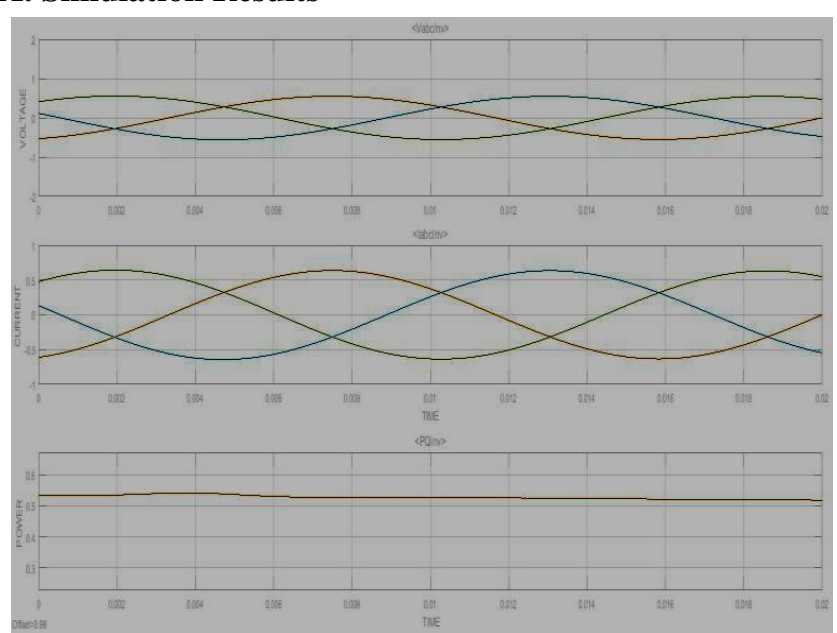

Fig. 4.6. Load voltage, load current and load power with fractional over voltage MPPT control

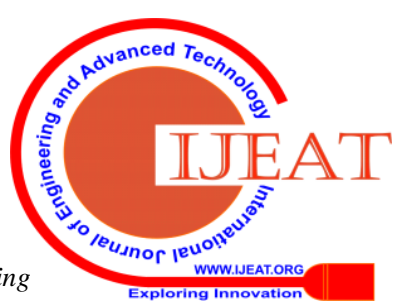




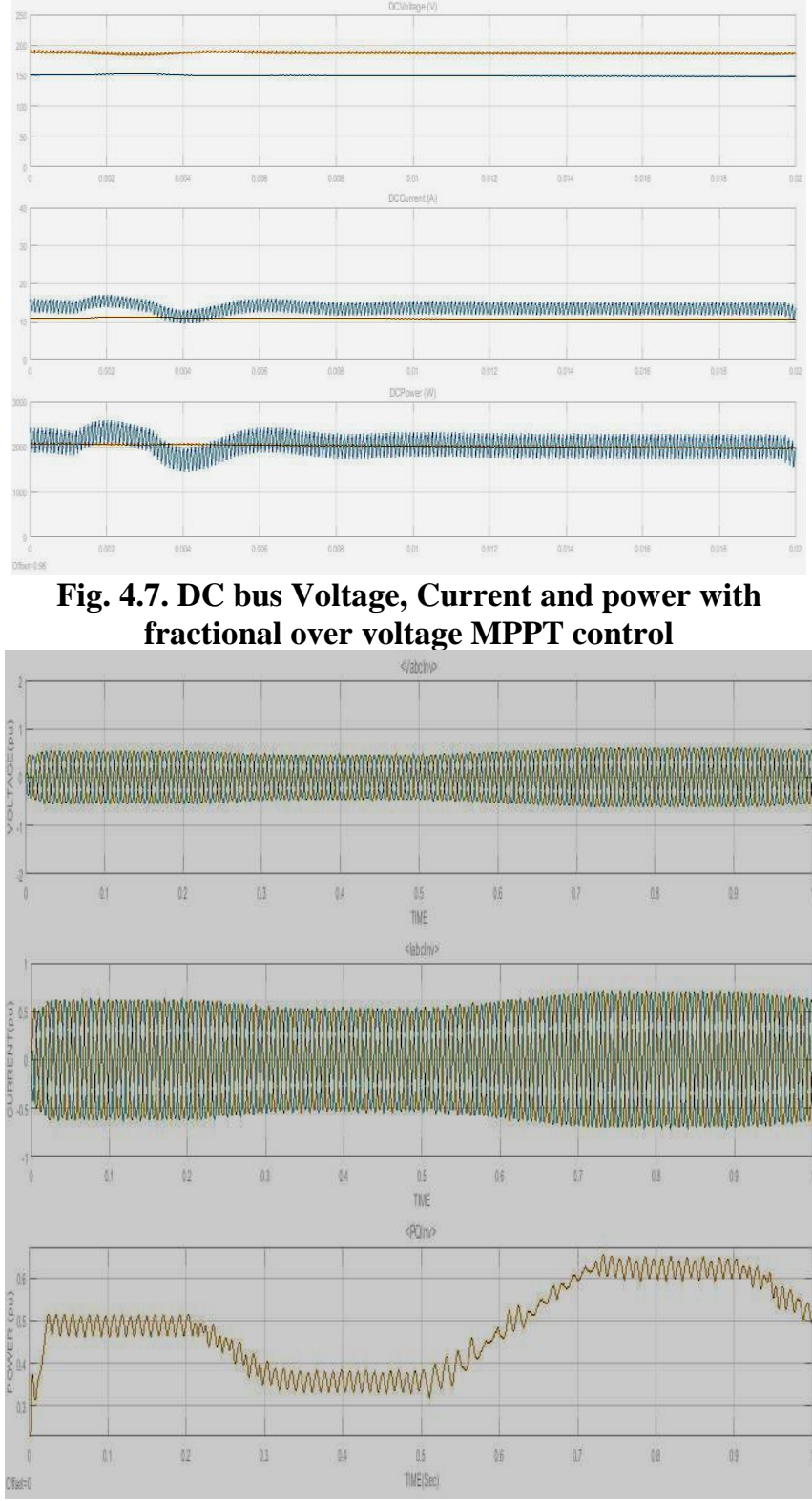

Fig. 4.8. Load voltage, load current and load power with P\&O MPPT control

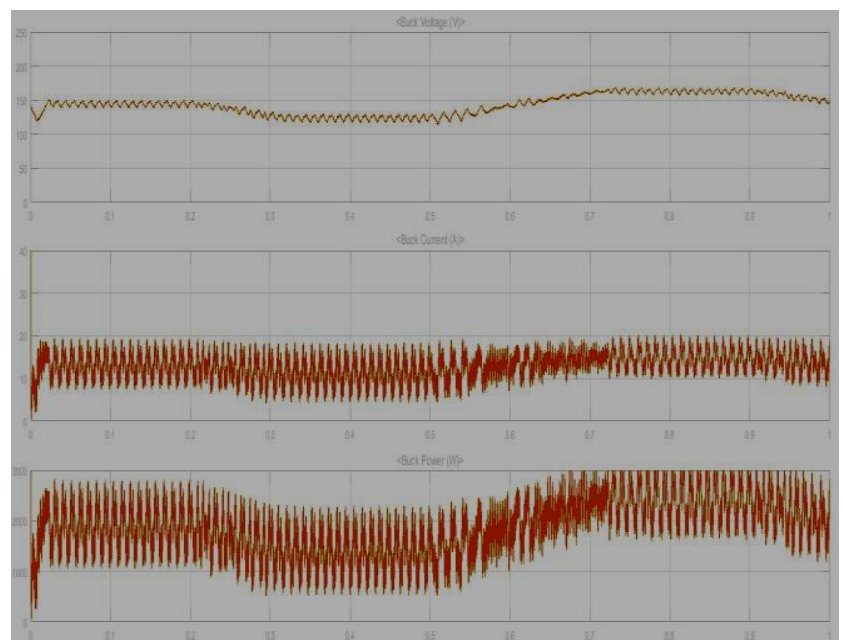

Fig. 4.9. DC bus Voltage, Current and power with P\&O MPPT control

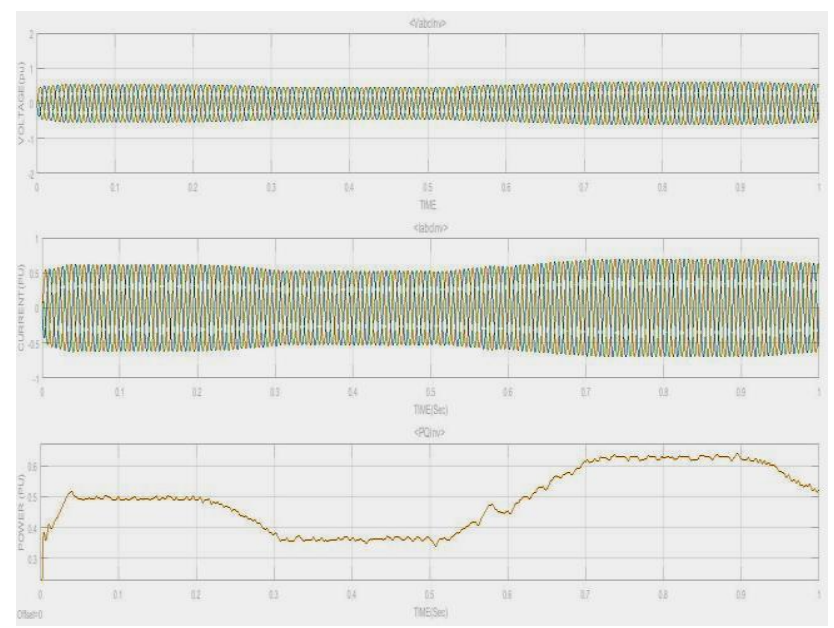

Fig. 4.10. Load Voltage, load Current and load Power with Incremental Conductance MPPT control

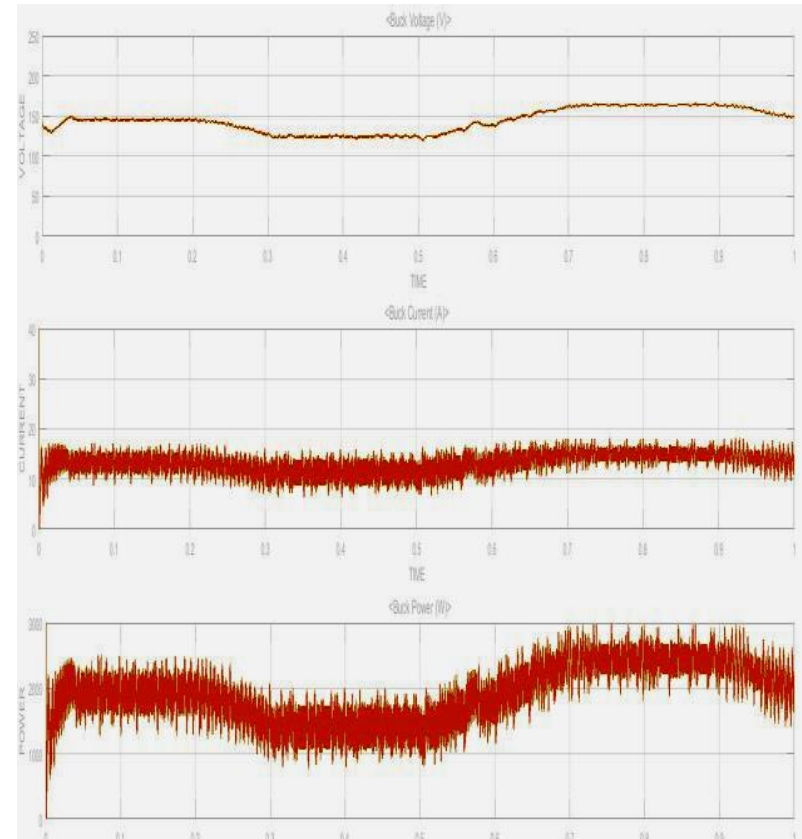

Fig.4.11. DC bus voltage, current and power with Incremental Conductance MPPT control

Table I: Comparison Result

\begin{tabular}{|c|c|c|c|c|c|c|c|c|c|c|}
\hline & & \multicolumn{3}{|c|}{ Perturo and observer } & \multicolumn{3}{|c|}{ Incementinal conductance } & \multicolumn{3}{|c|}{ Incremental conductance } \\
\hline & & Voltage & Cunrent & Power' & Voltage & Cument & Power & Voltage & Current & Power \\
\hline $\begin{array}{l}\text { Step } \\
\text { imadid }\end{array}$ & 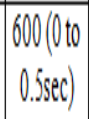 & 120 & 12 & 1440 & 124 & 15 & 1860 & 128 & 15 & 1920 \\
\hline ance & $\begin{array}{l}1000 \\
(0.5 t 0 \\
1 \mathrm{sec})\end{array}$ & 160 & 16 & 2560 & 162 & 19 & 3078 & 165 & 19 & 3135 \\
\hline
\end{tabular}

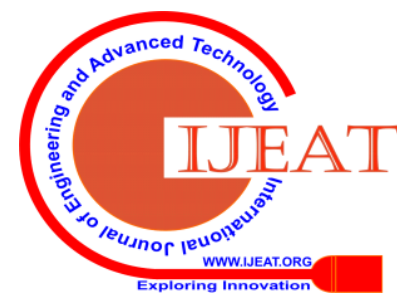




\section{CONCLUSION}

In this paper deals with a standalone Photovoltaic system connected with buck, IC method, P and O method, open circuit method for extracting most power at completely different status is presented. We will in general notice that the fundamental activity of DC-DC in PV framework is like middle power that alter the voltage levels such that extreme power may be pull out from the PV array. Dynamical voltage and current level changes a exact mounted burden to a variable burden. Fractional over Voltage MPPT Controller gives great controller to control the dc-dc for extracting more power from the PV while relate to other two MPPT strategies.

\section{REFERENCES}

1. Mohammed Ali Khalifa, Kamal Mohamed Saied, Miftahul Anwar and Muhammad Nizam, 'PV power system using maximum power point tracking (increment conductance algorithm)'

2. M.S.Sivagamasundari1, Dr. P. Melba Mary2, V. K. Velvizhi, Maximum power point tracking for photovoltaic system by Perturb and Observe method using buck boost.

3. Roberto Faranda, Sonia Leva Department of Energy Politecnico di Milano Piazza Leonardo da Vinci, 'Energy comparison of MPPT techniques for PV Systems'.

4. Mida Dris, Benattous Djilani.Department of Electrical Engineering, El Oued University(Algeria), 'Comparative study of algorithms (mppt) applied to photovoltaic systems'.

5. Hairul Nissah Zainudin Center of Foundation in Sciences,

CyberjayaUniversity College of Medical Sciences (Cyberjaya), 'Comparison study of maximum power point tracker techniques for pv systems'.

6. Lashab Abderezak,Bauzid Aissa,Snani Hamza, Laboratoire d'Electrotechnique de Constantine Universit'e des fr'eres Mentouri Constantine(Algerie), 'Comparative study of three MPPT algorithms For a photovoltaic system control'.

7. Abolfazl Halvaei Niasar Zahra Zare Fahimeh Rabiei Far Department of Electrical and Computer Engineering, University of Kashan(Iran), 'A low-cost p\&o based maximum power point tracking, combined with two- degree sun tracker'

8. Maiz Hadj Ahmed Mustapha, 'Design And Implementation Of Photovoltaic Water Pumping System'.

9. A Maximum Power Point Tracking Technique For Single-Phase Photovoltaic Systems With Reduced Dc-Link Capacitor

\section{AUTHORS PROFILE}

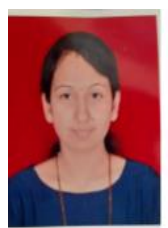

Megha S. Dokhale received the B. E. (Electrical) degree from SPPU, Pune University in 2017, appearing M.E.(Electrical) degree from SPPU, Pune from 2018.

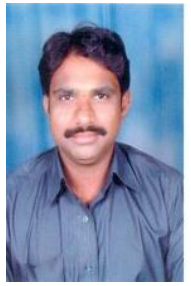

M.V. REDDY received the B. E. (Electrical \&Electronics Engg) degree from University of Madras in 2003, M.E.(Electrical) degree from Anna university, Chennai, in 2006, and pursuing Ph.D in electrical engineering from Osmania university, Hyderabad. He has been with Electrical Engineering Department, GES's RHSCOEMS \&R ,Nashik. His research areas are Power Electronics, Flexible Ac

Transmission Systems, and Multi level converters. The author has published three papers in international journals and three papers publishedin proceedings of international conferences.

He is a Life Member of Indian Society for Technical Education.

(LMISTE).

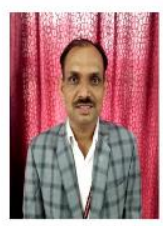

Deepak M. Sonje received the B. E. (Electrical) degree from Shivaji Universityin 1999, M.E.(Electrical) degree from SPPU, Pune, in 2009 , and awarded Ph. Ddegree in 2019 in electrical engineering from Sardar Vallabhbhai National Institute of Technnology, Surat. Since, 2010 he has been with Electrical Engineering Department,GES' RHSCOEMS\&R, Nashik. His research areas are fault diagnosis of electrical machines, machine learning tools, modeling of electrical machines and drives. The author has publishedfour papers in international journals and four papers published in proceedings of international conferences. He is a member of the Institution of Engineering and Technology (IET). 